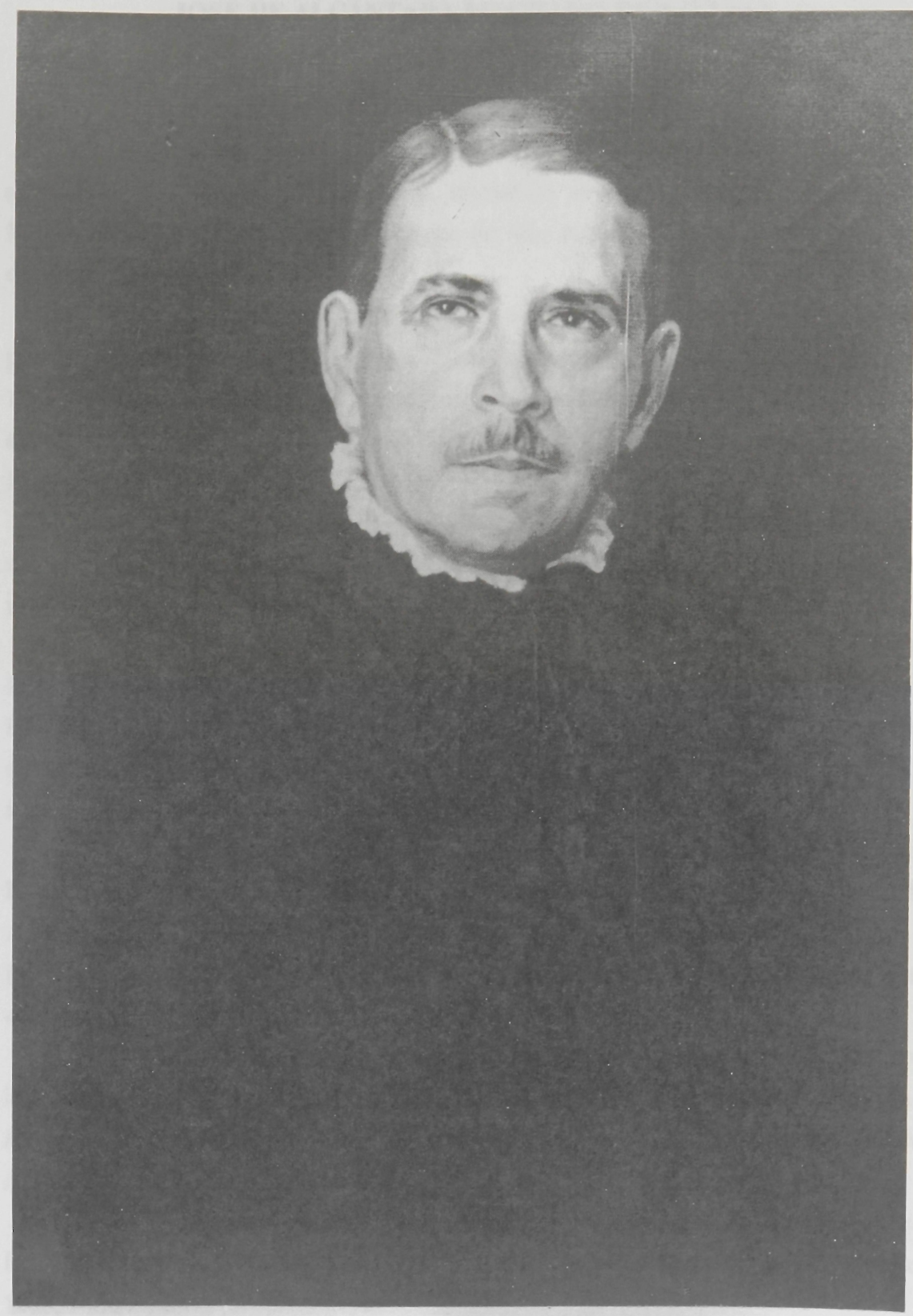

$=$ ALCANTARA MACHADO 



\section{JOSÉ DE ALCÂNTARA MACHADO D'OLIVEIRA}

(1931-1935)

Nasceu em Piracicaba a 19 de outubro de 1875.

$\mathrm{Fez}$ os seus primeiros estudos na Escola Neutralidade e os secundários no Colégio Moretzshon, iniciando os seus preparatórios em 1887. Matriculou-se na Faculdade de Direito de São Paulo em 1890 e recebeu o grau de bacharel em 1893.

Aprovado em concurso, foi nomeado lente substituto, tomando posse em setembro de 1895, quando recebeu o grau de doutor. Em junho de 1915 foi declarado professor substituto de Medicina Pública, sendo que, em agosto de 1925, foi nomeado professor catedrático de Medicina Pública, atual Medicina Legal.

De 1927 a 1930 foi vice-diretor desta Faculdade, sendo nomeado, em 1931, diretor, cargo que exerceu até 1935. Durante a sua gestão, foi inaugurado o prédio atual da Faculdade, em 1934.

Na esfera política, exerceu os cargos de vereador municipal (19111916), deputado estadual (1915-1924), senador estadual (1924-1930), deputado e líder da bancada paulista na Assembléia Nacional Constituinte (1933-1934) e senador federal (1935). Foi em sua residência que a intelectualidade paulista se reuniu para acertar o fim do Movimento Constitucionalista.

Foi membro fundador e presidente da Sociedade de Medicina Legal e Criminologia de São Paulo, sócio correspondente do Instituto dos Advogados Brasileiros, do Instituto Histórico e Geográfico Brasileiro, da Faculdade Paulista de Filosofia e Letras, da Escola de Sociologia e Política, entre outros.

No campo literário, seguindo os passos de seu pai e de seu avô, iniciou cedo a vida literária, fundando um periódico manuscrito intitulado Rouxinol. Quando acadêmico, colaborou com os pseudônimos de "Álvaro Alvares" e "Pero Peres" na revista A Semana.

Pertenceu a duas Academias de Letras, a Paulista (1919) e a Brasileira (1913), substituindo nesta Silva Ramos. Como historiador, lançou, em 1929, Vida e morte do bandeirante.

Faleceu a $1^{\circ}$ de abril de 1941 nesta capital. 


\section{Obras Publicadas}

Do momento de formação dos contratos por correspondência: ensaio. São Paulo :

Typ. da Companhia Industrial de São Paulo, 1892.

A embriaguez e a responsabilidade criminal: theses e dissertação. São Paulo :

Salesianas, 1894.

Ensaio medico-legal sobre o hypnotismo: dissertação e theses. São Paulo :

Industrial, 1895.

Suicidios na capital de São Paulo. In: Terceira Reunião do Congresso Scientifico

Latino-Americano. Rio de Janeiro, 1910. t. 4.

Problemas municipaes. São Paulo : O Estado de S. Paulo, 1917.

Honorarios medicos: doutrina, legislação, jurisprudencia. São Paulo : O Estado de S. Paulo, 1919.

Vida e morte do bandeirante. Belo Horizonte : Itatiaia; São Paulo : EDUSP, 1980.

O ensino na pericia (these official: $2^{\mathrm{a}}$ parte). In: Actas da Segunda Conferencia Latino-Americano de Neurologia, Psychiatria e Medicina Legal. São Paulo, 1931. t. 1.

O ensino de medicina legal nas escolas de Direito. Revista de Criminologia e Medicina Legal, São Paulo, 1928, v. 2, ns. 3 e 4.

Acção da bancada paulista "Por São Paulo Unido" na Assembléa Constituinte.

Programa da "Chapa Unica" e a nova Constituição. São Paulo : Imprensa Official do Estado, 1935.

Gonçalves de Magalhães ou o romântico arrependido. São Paulo : Acadêmica, 1936.

Brasílio Machado: 1848-1919. Rio de Janeiro : José Olympio, 1937.

Projecto do codigo criminal brasileiro: organizado por incumbencia do professor dr. Franciso Campos, Ministro da Justiça. São Paulo : Empresa Graphica da Revista dos Tribunais, 1938. 